\title{
Protective activity of glycolipid antigen against infection by Leptospira interrogans serovar canicola
}

\author{
T. Masuzawa, ${ }^{*}$ T. Matsumoto, R. Nakamura, R. Suzuki, T. Shimizu and Y. Yanagihara \\ Department of Microbiology, School of Pharmaceutical Sciences, University of Shizuoka, 395 Yada, Shizuoka 422, Japan
}

(Received 14 August 1989; revised 5 October 1989; accepted 23 October 1989)

\begin{abstract}
A protective glycolipid antigen (PAg) was extracted from Leptospira interrogans serovar canicola with chloroform/methanol/water (1:2:0.8, by vol.) and partially purified by silica gel column chromatography. The PAg elicited a protective response in hamsters and in cyclophosphamide-treated mice subsequently challenged with homologous Leptospira. The PAg band was detected as a single smear-like band, corresponding to a protein of 23$30 \mathrm{kDa}$, by silver-staining in SDS-PAGE. In immunoblots, this band reacted with a monoclonal antibody, A5, which agglutinated serovar canicola and recognized a serovar-specific antigen. Furthermore, the PAg did not migrate on silica gel TLC, but was detected at the origin as a ninhydrin- and naphthol-positive spot. This suggests that PAg is a hydrophilic molecule with a carbohydrate chain that contains amino groups, possibly as amino sugars.
\end{abstract}

\section{Introduction}

Vaccination is thought to be the most effective way to control leptospirosis and chemically inactivated bacterins are used in many countries (Bey \& Johnson, 1986). Previous studies have shown that the outer-envelope fraction of Leptospira induces better protection than lyophilized whole cells (Auran et al., 1972; Bey et al., 1974). Monoclonal antibody (mAb) against leptospiral 'lipopolysaccharide' (LPS) protects newborn guinea pigs from experimental infection by Leptospira (Jost et al., 1986). The partial purification and protective activity of a glycolipid antigen (PAg) of serovar lai (Icterohaemorragiae serogroup) has been reported (Masuzawa et al., $1989 b$ ).

Ono et al. (1987) purified the glycolipid antigen from L. interrogans serovar canicola (Canicola serogroup) and characterized its chemical properties. By using mAb A5 against $L$. interrogans serovar canicola, it appeared that antigenic determinants of the agglutinogen of Leptospira were present in the carbohydrate moiety of the outer envelope and that $\mathrm{mAb} A 5$ protected hamsters from infection (Yanagihara et al., 1988). In the present study, the purification of the PAg of serovar canicola was attempted. Its protective activity in hamsters and cyclophosphamide-treated mice was evaluated and its

\footnotetext{
Abbreviations: CMW, chloroform/methanol/water; EIA, enzyme immuno-assay; Fr I, fraction I; LLS, lipopolysaccharide-like substance; mAb, monoclonal antibody; PAg, protective antigen.
}

chemical nature characterized by TLC and SDSPAGE.

\section{Methods}

Organisms. For the preparation of antigen, L. interrogans serovar canicola strain Moulton was cultured in Baseman-Cox medium (Baseman \& Cox, 1969) at $30^{\circ} \mathrm{C}$ for $7 \mathrm{~d}$. A virulent strain was maintained by passage in hamsters; it was not subcultured more than twice.

Preparation of PAg. PAg was extracted from lyophilized cells as previously described (Masuzawa et al., 1989b). The extract was separated into two fractions: a chloroform fraction and a methanol/ water fraction. No differences in SDS-PAGE profiles (data not shown) nor in protective activity were observed between the chloroform and methanol/water fractions (Table 1). The two fractions were therefore pooled [the chloroform/methanol/water (CMW) extract]. The CMW extract obtained was further purified by silica gel (silica gel 60 ; Merck) column chromatography. Its elution profile was monitored by SDSPAGE, and two fractions - fraction I (Fr I) and PAg - were obtained. Fr I was eluted with chloroform/methanol/water $(1: 2: 0 \cdot 6$, by vol.); PAg was eluted with chloroform/methanol/water $(1: 2: 0 \cdot 8$, by vol.). After evaporation of the solvent under reduced pressure below $40^{\circ} \mathrm{C}$, each fraction was suspended in a small amount of distilled water and lyophilized.

SDS-PAGE and immunoblot. The purity of $\mathrm{Fr} I$ and $\mathrm{PAg}$ was monitored by SDS-PAGE using a $15 \%$ ( $w / v$, acrylamide) gel according to the method of Laemmli (1970). After electrophoresis, gels were either stained by the silver staining method of Tsai \& Frasch (1982) and with Coomassie brilliant blue R-250 or transferred onto a nitrocellulose membrane (pore size $0.2 \mu \mathrm{m}$; Toyo-roshi Co.) by the method of Towbin et al. (1979). The antigen bands on the membrane were immunostained with mAb A5 (Masuzawa et al., 1989a), which was raised against the agglutinogen of $L$. interrogans serovar canicola. 


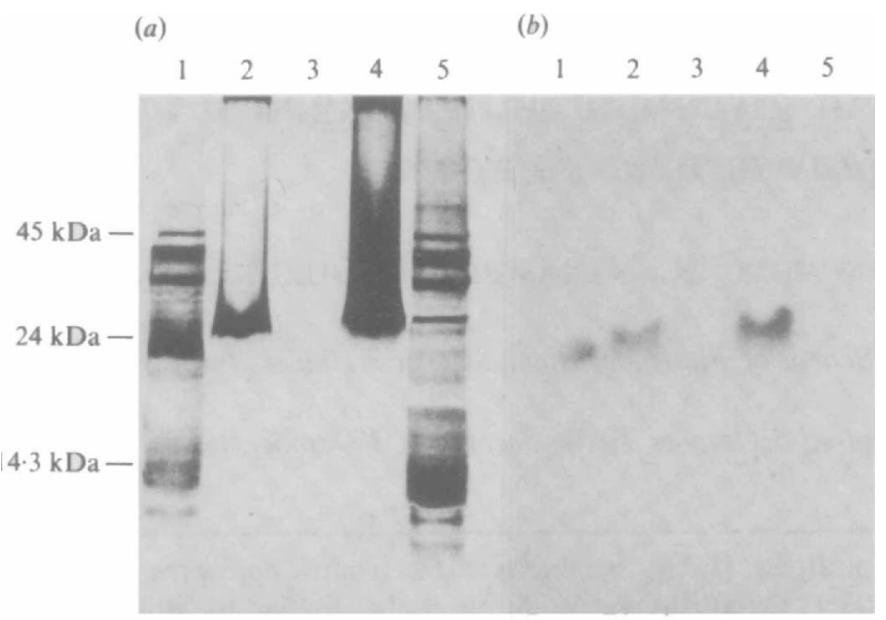

Silver stain

Immunostain

Fig. 1. Antigen profiles of $L$. interrogans serovar canicola as shown by SDS-PAGE and immunostain. (a) Silver-stained gel; (b) immunostaining with $\mathrm{mAb}$ A5 as primary antibody against serovar canicola (right). Lanes: 1 , whole cells; 2 , CMW extract; 3, fraction I; 4, PAg; 5, residual fraction.
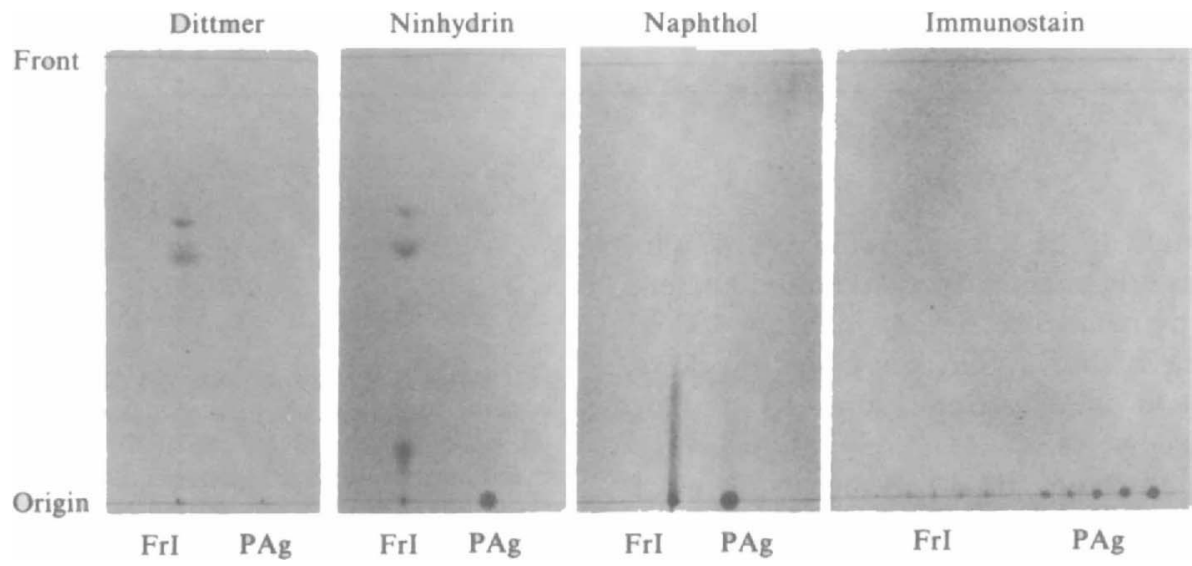

Fig. 2. Antigen profiles of $L$. interrogans serovar canicola as shown by TLC and TLC/EIA. Each antigen $(50 \mu g)$ was spotted on the TLC plate and developed in a solution of methyl acetate/1-propanol/chloroform/methanol/0.25\% potassium chloride $(25: 20: 20: 20: 17$, by vol.). Antigen spots were detected by Dittmer reagent (phospholipid), ninhydrin reagent (amino group) and naphthol reagent (carbohydrate) on TLC plates. In the immunostain, each antigen was spotted from the left with $0 \cdot 2,0 \cdot 4,0 \cdot 6,0 \cdot 8$ and $1 \cdot 0 \mu \mathrm{g}$ of material and developed with the above solution. Spots of specific antigen were visualized by immunostaining with mAb A5 as the primary antibody.

Protection tests. The protective immune response induced by each fraction and by whole cells was evaluated in hamsters and mice. Male Golden hamsters (4-week-old) and BALB/c mice were vaccinated intraperitoneally with the preparations of serovar canicola on day 0 and 7 , respectively. The BALB/c mice were also injected intraperitoneally (300 $\mathrm{mg} \mathrm{kg}^{-1}$ ) with cyclophosphamide (Sigma) on day 12, in order to suppress antibody production (Adler et al., 1976, 1977). These animals were challenged intraperitoneally with virulent serovar canicola culture on day 14. The survival of hamsters and mice was observed for $14 \mathrm{~d}$ after the challenge, at which time the survivors were killed and their kidneys removed. The kidneys were inoculated into Korthof medium and incubated at $30^{\circ} \mathrm{C}$ for $14 \mathrm{~d}$ to detect the presence of Leptospira.

TLC and TLC/enzyme-immuno assay (EIA). Fr I or PAg were spotted onto plastic TLC plates (Polygram Sil G; Marchery-Nagel) and developed with methyl acetate/1-propanol/chloroform/methanol/ $0.25 \%$ (w/v) potassium chloride $(25: 20: 20: 20: 17$, by vol.). Phosphati- dylethanolamine, lyso-phosphatidylethanolamine, phosphatidylserine, phosphatidylcholine and sphingomyelin (Sigma) were used as standard phospholipids. Each spot was detected by Dittmer reagent for phospholipids, naphthol reagent for carbohydrates and ninhydrin reagent for amino groups. TLC/EIA was done with $\mathrm{mAb} A 5$ as the primary antibody by the method of Higashi et al. (1984).

\section{Results}

\section{SDS-PAGE, immunoblot, TLC and TLC/EIA}

After silver staining of SDS-PAGE gels, the CMW extract and PAg of $L$. interrogans serovar canicola appeared as a smear-like band, corresponding to protein 
Table 1. Protective effect of PAg against L. interrogans serovar canicola infection

Hamsters were injected intraperitoneally with the stated immunizing agent on day 0 and 7 and challenged intraperitoneally with $L$. interrogans serovar canicola $\left(1.25 \times 10^{8}\right.$ cells per hamster $)$ on day 14. NT, Not tested.

\begin{tabular}{lccc}
\hline \hline Immunizing & $\begin{array}{c}\text { Dose per } \\
\text { hamster } \\
(\mu \mathrm{g})\end{array}$ & $\begin{array}{c}\text { Survivors after } \\
14 \mathrm{~d} / \text { no. of } \\
\text { hamsters tested } \\
\text { (\% survivors) }\end{array}$ & $\begin{array}{c}\text { Kidney culture } \\
\text { (positive/ } \\
\text { survivors) }\end{array}$ \\
\hline Whole & 5.0 & $4 / 5(80)$ & $0 / 4$ \\
cells & 1.0 & $4 / 5(80)$ & $0 / 4$ \\
Chloroform & 20.0 & $5 / 5(100)$ & $0 / 5$ \\
fraction & 5.0 & $4 / 5(80)$ & $0 / 4$ \\
& 1.0 & $4 / 5(80)$ & $0 / 4$ \\
Methanol/water & 20.0 & $5 / 5(100)$ & $0 / 5$ \\
fraction & 5.0 & $3 / 5(60)$ & $0 / 3$ \\
& 1.0 & $3 / 5(60)$ & $0 / 3$ \\
Residual & 20.0 & $0 / 5(0)$ & $\mathrm{NT}$ \\
fraction & 5.0 & $0 / 5(0)$ & $\mathrm{NT}$ \\
Saline & 0 & $0 / 5(0)$ & $\mathrm{NT}$ \\
(control) & & & \\
\hline \hline
\end{tabular}

Table 2. Protective effect of PAg against L. interrogans serovar canicola infection

Hamsters were injected intraperitoneally with the stated immunizing agent on day 0 and 7 and challenged intraperitoneally with $L$. interrogans serovar canicola $\left(5.6 \times 10^{7}\right.$ cells per hamster $)$ on day 14 . NT, Not tested.

\begin{tabular}{lccc}
\hline \hline Immunizing & $\begin{array}{c}\text { Dose per } \\
\text { hamster } \\
(\mu \mathrm{g})\end{array}$ & $\begin{array}{c}\text { Survivors after } \\
14 \mathrm{~d} / \text { no. of } \\
\text { hamsters tested } \\
(\% \text { survivors) }\end{array}$ & $\begin{array}{c}\text { Kidney culture } \\
\text { (positive/ } \\
\text { survivors) }\end{array}$ \\
\hline Whole & 10.0 & $5 / 5(100)$ & $0 / 5$ \\
cells & 1.0 & $5 / 5(100)$ & $0 / 5$ \\
Fraction I & 10.0 & $0 / 5(0)$ & $\mathrm{NT}$ \\
& 1.0 & $0 / 5(0)$ & $\mathrm{NT}$ \\
PAg & 10.0 & $4 / 5(80)$ & $0 / 4$ \\
& 1.0 & $5 / 5(100)$ & $0 / 5$ \\
Residual & 10.0 & $0 / 5(0)$ & $\mathrm{NT}$ \\
fraction & 1.0 & $0 / 4(0)$ & $\mathrm{NT}$ \\
Saline & 0 & $0 / 5(0)$ & $\mathrm{NT}$ \\
(control) & & & \\
\hline \hline
\end{tabular}

of molecular mass about 23-30 kDa (Fig. 1). Coomassie blue staining failed to reveal the band in the CMW, Fr I and PAg lanes (data not shown). Furthermore, PAg of $L$. interrogans serovar canicola only reacted with $\mathrm{mAb} \mathrm{A} 5$ in the immunostain. The band found in PAg was not detected in the extraction residue or in Fr I.

TLC (Fig. 2) showed that Fr I consisted of two spots of Dittmer- and ninhydrin-positive material with $R_{F}$
Table 3. Protective effect of PAg against $L$. interrogans serovar canicola infection in cyclophosphamide-treated mice

Mice were injected intraperitoneally with the stated immunizing agent on day 0 and 7 and injected intraperitoneally with cyclophosphamide $\left(300 \mathrm{mg} \mathrm{kg}^{-1}\right)$ on day 12 and challenged intraperitoneally with $L$. interrogans serovar canicola $\left(1.0 \times 10^{8}\right.$ cells per mouse $)$ on day 14 . NT, Not tested.

\begin{tabular}{lcccc}
\hline Immunizing & $\begin{array}{c}\text { Dose } \\
\text { per } \\
\text { mouse } \\
(\mu \mathrm{g})\end{array}$ & $\begin{array}{c}\text { Mean survival } \\
\text { time } \pm \text { SD (d) }\end{array}$ & $\begin{array}{c}\text { Survivors after } \\
14 \mathrm{~d} / \text { no. of } \\
\text { mice tested } \\
\text { (\% survivors) }\end{array}$ & $\begin{array}{c}\text { Kidney } \\
\text { culture } \\
\text { (positive/ } \\
\text { survivors) }\end{array}$ \\
\hline Whole & 10.0 & $15.0 \pm 0$ & $5 / 5(100)$ & $0 / 5$ \\
cells & 1.0 & $15.0 \pm 0$ & $5 / 5(100)$ & $0 / 5$ \\
& 0.1 & $11.2 \pm 3.5$ & $0 / 3(0)$ & NT \\
PAg & 10.0 & $15.0 \pm 0$ & $5 / 5(100)$ & $0 / 5$ \\
& 1.0 & $13.4 \pm 3.6$ & $4 / 5(80)$ & $0 / 4$ \\
& 0.1 & $9.8 \pm 5.0$ & $2 / 5(40)$ & $0 / 2$ \\
Saline & 0 & $10.0 \pm 1.4$ & $0 / 5(0)$ & NT \\
(control) & & & & \\
\hline$=$
\end{tabular}

values of 0.65 and 0.52 , which were identified as phosphatidylethanolamine and lyso-phosphatidylethanolamine, respectively, by comparison with standard phospholipids. Only one spot of ninhydrin- and naphthol-positive material was observed in PAg at the origin of the chromatogram and it was immunostained by mAb A5. The Fr I sample was not immunostained.

\section{Protective activity in hamster and in cyclophosphamide- treated mice}

Both the chloroform fraction and the methanol/water fraction exhibited the same degree of protective activity as whole cells (Table 1). However, no protective effect was elicited by the residual fraction. These results indicated that the protective antigen was efficiently extracted by the CMW method from dried cells of serovar canicola.

The CMW extract of serovar canicola, after further purification by silica gel column chromatography, had a protective activity which was comparable with that of lyophilized whole cells (Table 2). Whole cells and PAg appeared to protect hamsters from infection by homologous Leptospira: Leptospira were not detected in the kidneys of any survivors. On the other hand, Fr I and the extraction residue did not show any protective activity.

Protective activity in cyclophosphamide-treated mice (antibody production suppressed) was compared using whole cells and PAg (Table 3). Immunization with PAg or whole cells at doses of 1 to $10 \mu \mathrm{g}$ per animal elicited protective activity such that live leptospires were not recovered from the kidneys of the survivors. Administration of $0.1 \mu \mathrm{g}$ whole cells per animal was ineffective 
against homologous infection, but the same dose of $\mathrm{PAg}$ produced a weak protective effect.

\section{Discussion}

A similar electrophoretic profile to that found in this study was observed in a PAg preparation of serovar lai (Masuzawa et al., 1989 b). Electrophoretic profiles of PAg from serovar canicola were quite similar to that of the 'lipopolysaccharide-like substance, LLS' of serovar canicola prepared by Shimizu et al. (1987) and that of 'LPS' of serovar copenhageni (data not shown) provided by Dr B. Adler (Jost et al., 1986). The yield of purified LLS, extracted from leptospiral cells by the hotphenol/water method, was only a small percentage of the starting material (Shimizu et al., 1987). The PAg prepared by the CMW method in this study gave yields from dried cells as high as about $20 \%$ and it was rarely contaminated with protein. The residual fraction after CMW extraction did not contain the band which corresponded to PAg by silver stain. Furthermore, the PAg showed a potent protective effect, but the residual fraction was ineffective against leptospiral infection. The evidence demonstrated that the PAg was satisfactorily extracted from leptospiral cells by CMW extraction and that it was the principal protective antigen of leptospires. In experimental lethal infection of cyclophosphamide-treated mice, which were more sensitive than hamsters to leptospiral infection, $0 \cdot 1 \mu \mathrm{g}$ of PAg per mouse gave partial protection, and it appeared that the protective effect of PAg was more potent than that of whole cells on a weight for weight basis.

Our study confirms that PAg can be effectively extracted from leptospiral cells by CMW treatment and can be purified by silica gel column chromatography. Furthermore, PAg was immobile on silica gel TLC: it remained at the origin and was detected by ninhydrin and naphthol. This suggests that PAg might have hydrophilic carbohydrate chains with amino groups, which could be amino sugars.

Further studies on the chemical composition and LPSlike activity of PAg are now in progress.

This study was supported by a Grant-in-Aid for Scientific Research (62570195) and a Grant-in-Aid for Encouragement of Young Scientists (63771964 and 01771984) from the Ministry of Education, Science, and Culture of Japan, and by a Grantin-Aid for Scientific Research from the Shizuoka Prefectural Foundation for the Advancement of Education, Japan.

\section{References}

ADLER, B. \& FAINE, S. (1976). Susceptibility of mice treated with cyclophosphamide to lethal infection with Leptospira interrogans serovar pomona. Infection and Immunity 14, 703-708.

ADLER, B. \& FAINE, S. (1977). Host immunological mechanisms in the resistance of mice to leptospiral infections. Infection and Immunity 17, 67-72.

Auran, N. E., Johnson, R. C. \& Ritizi, M. D. (1972). Isolation of the outer sheath of Leptospira and its immunogenic properties in hamsters. Infection and Immunity 5, 968-975.

BASEMAN, J. B. \& Cox, C. D. (1969). Intermediate energy metabolism of Leptospira. Journal of Bacteriology 97, 992-1000.

BEY, R. F. \& JoHnson, R. C. (1986). Current status of leptospiral vaccines. Progress in Veterinary Microbiology and Immunology 2, 175197.

Bey, R. F., AURAN, N. E. \& Johnson, R. C. (1974). Immunogenicity of whole cell and outer envelope leptospiral vaccines in hamsters. Infection and Immunity 10, 1051-1056.

Higashi, H., Fukui, Y., Ueda, S., Kato, S., Hirabatashi, Y., Matsumoto, M. \& NaIKI, M. (1984). Sensitive enzyme-immunostaining and densitometric determination on thin-layer chromatography of $\mathrm{N}$-glycolylneuraminic acid-containing glycosphingolipids, Hanganutziu-Deicher antigen. Journal of Biochemistry 95, 15171520 .

Jost, B. H., Adler, B., Vinh, T. \& FaINe, S. (1986). A monoclonal antibody reacting with a determinant on leptospiral lipopolysaccharide protects guinea pigs against leptospirosis. Journal of Medical Microbiology 22, 269-275.

LAEMMLI, U. K. (1970). Cleavage of structural proteins during the assembly of the head of bacteriophage T4. Nature, London 227, 680685.

Masuzawa, T., Sekiguchi, T., Shimizu, T., Iwamoto, Y., Morita, T., Mifuchi, I. \& Yanagihara, Y. (1989a). Monoclonal antibody against Leptospira interrogans serovar canicola. Chemical and Pharmaceutica! Bulletin 37, 414-417.

Masuzawa, T., Nakamura, R., Shimizu, T., Iwamoto, Y., Morita, T. \& YaNAGIHARA, Y. (1989b). Immunological characteristics of the glycolipid antigen of Leptospira interrogans serovar lai. Infection and Immunity 57, 2502-2506.

Ono, E., Takase, H., NaIKi, M. \& Yanagawa, R. (1987). Purification, characterization and serological properties of a glycolipid antigen reactive with a serovar-specific monoclonal antibody against Leptospira interrogans serovar canicola. Journal of General Microbiology 133, 1329-1336.

Shimizu, T., Matsusaka, E., Nagakura, N., Takayanagi, K., Masuzawa, T., Iwamoto, Y., Morita, T., Mifuchi, I. \& YANAGIHARA, Y. (1987). Chemical properties of lipopolysaccharidelike substance (LLS) extracted from Leptospira interrogans serovar canicola strain Moulton. Microbiology and Immunology 31, 717725.

Towbin, H., Staehelin, T. \& GoRdon, J. (1979). Electrophoretic transfer of proteins from polyacrylamide gels to nitrocellulose sheets: procedure and some applications. Proceedings of the National Academy of Sciences of the United States of America 76, 43504354.

TSaI, C. M. \& Frasch, C. E. (1982). A sensitive silver stain for detecting lipopolysaccharide in polyacrylamide gels. Analytical Biochemistry 119, 115-119.

Yanagihara, Y., Masuzawa, T., Matsumoto, T., Shimizu, T. \& TAKAYANAGI, K. (1988). Monoclonal antibody against surface antigen of Leptospira interrogans serovar canicola. Israel Journal of Veterinary Medicine 44, 56-58. 